\title{
The use of a dermal substitute and thin skin graft in the cure of lower limbs wounds from vasculitis: observational study
}

\author{
V Padovano Sorrentino*, A Della Corte, F Campitiello, F Freda, P Petronella, S Canonico \\ From de Senectute: Age and Health Forum \\ Catanzaro, Italy. 5-7 December 2009
}

\section{Background}

In patients with lower limbs wounds from vasculitis reconstructive surgery with skin grafts can be considered, but this treatment likely fails because of the position, width, and depth of the lesion(s). In these patients a new therapeutic prospect is the use of a dermal matrix that stimulates the production of endogenous collagen before repair with skin graft autografting.
Integra $^{\circ}$ is a semibiological implant consisting of a two-layered membrane that produces a histo-inductive and histo-conductive action on mesenchyme, leading to the formation of normal derma.

\section{Materials and methods}

This observational study enrolled six over 65 years old patients with vasculitis and leg ulcers dating at least 1 years. All ulcers, for a total of 39 lesions, were very

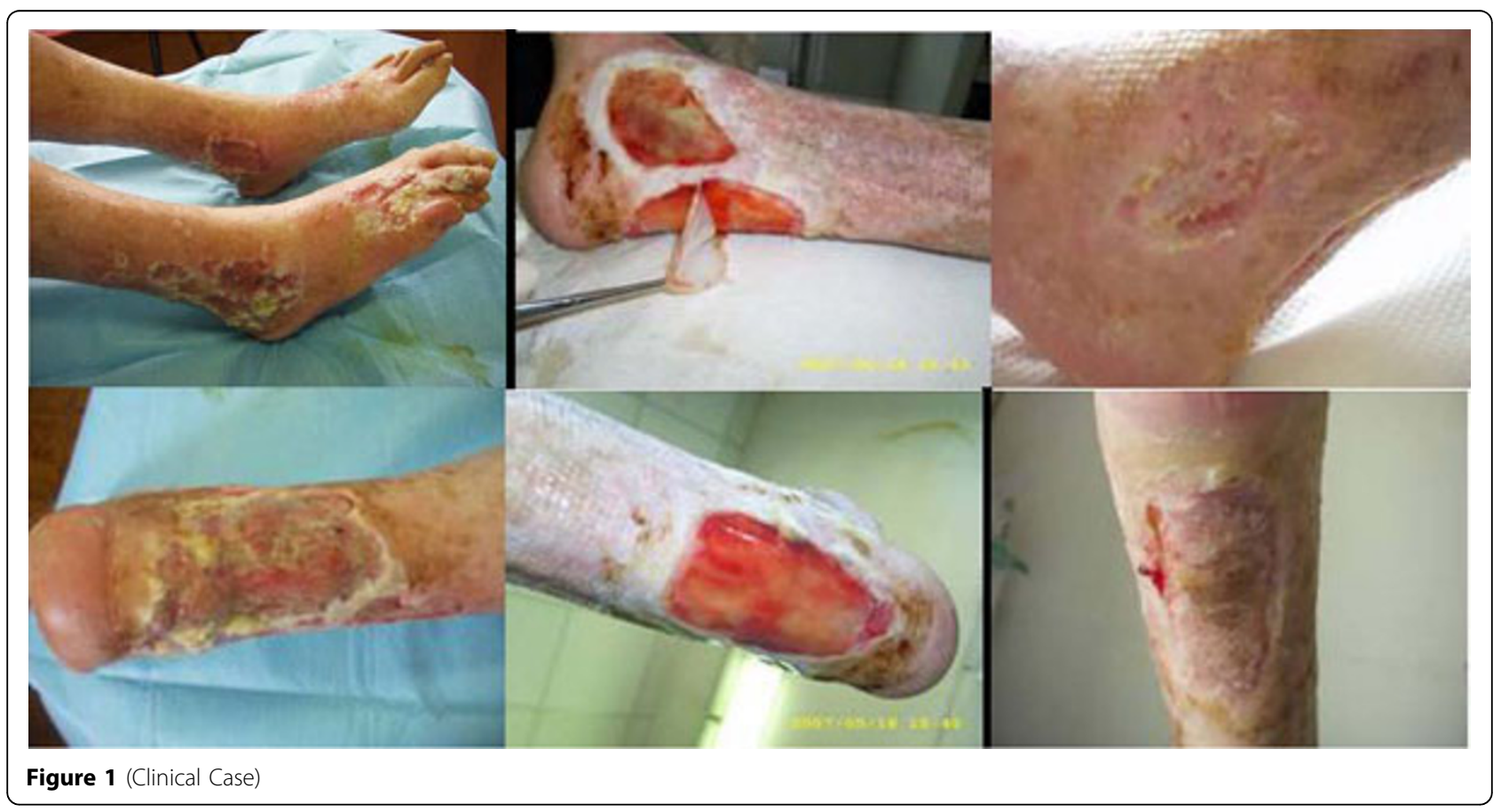

Department of Gerontology, Geriatrics and Metabolic Diseases, Second University of Naples, Naples, Italy 
painful. After surgical debridement of the wounds, the dermal matrix was modelled and applied. After 21 days, the attachment of the artificial dermis was tested, the patients were re-admitted for thin skin grafting.

\section{Results}

In all patients, at the first follow-up, a notable reduction in pain, exudates and perilesional edema was ascertained. After 2 weeks, progressive substitution of granulation tissue with new yellow gold derma became evident in all the patients. After 21 days, the dermal matrix was completely integrated with the guest tissue. In 5 patients, attachment of the skin graft was complete, and in one patient, it was partial but nevertheless superior for $80 \%$ of the surface. Even in this case, complete healing of the lesions was achieved within 4 weeks at most. All patients were checked for a minimum of 6 months, and none suffered an ulcerous recurrence.

\section{Discussion}

In our series, Integra ${ }^{\circ}$ allowed for the complete refilling of the loss of tissue, the rapid disappearance of pain, and the rapid regeneration of a permanent dermis. (Figure 1)

Published: 19 May 2010

\section{Reference}

1. Canonico S: The Use of a Dermal Substitute and Thin Skin Grafts in the Cure of "Complex" Leg Ulcers. Dermatol Surg 2009, 35:195-200.

doi:10.1186/1471-2318-10-S1-A68

Cite this article as: Sorrentino et al:: The use of a dermal substitute and thin skin graft in the cure of lower limbs wounds from vasculitis: observational study. BMC Geriatrics 2010 10(Suppl 1):A68.
Submit your next manuscript to BioMed Central and take full advantage of:

- Convenient online submission

- Thorough peer review

- No space constraints or color figure charges

- Immediate publication on acceptance

- Inclusion in PubMed, CAS, Scopus and Google Scholar

- Research which is freely available for redistribution

Submit your manuscript at www.biomedcentral.com/submit 